\title{
Rapid incremental methods for the determination of serum iron and iron-binding capacity
}

\author{
R. N. BEALE, J. O. BOSTROM, AND R. F. TAYLOR \\ From the Institute of Clinical Pathology and Medical Research, \\ the Department of Public Health, Sydney, Australia
}

SYNOPSIS Rapid methods depending on differential absorptiometry are described for the deter mination of the transferrin iron content and the latent iron-binding capacity of blood serum. . Each determination requires as little as $0.5 \mathrm{ml}$. serum. The methods are well adapted for routineo use in the 'average' laboratory. Three or four sera may be completely analysed in 30 minutes. Alloperations are carried out in the cells or tubes used for the colorimetric measurements, no precipi- $-\Phi$ tation or heating being employed at any stage. Critical investigations of the reliability of the methods are attempted and ranges of normal values are included.

The growing interest in iron metabolism and transport in man has created the need for methods for the determination of serum iron and iron-binding capacity which can be used routinely in the average clinical laboratory with the minimum expenditure of time, reagents, and equipment. The number and various types of method published indicate the value of iron analyses as aids in the diagnosis and treatment of various blood dyscrasias and abnormalities in iron metabolism, as typified by iron-deficiency anaemias, haemochromatosis, and the ageing process.

Earlier work on serum iron determination has been reviewed by Hemmeler (1951), Laurell (1952), and Ramsay (1958). Most methods involve the use of acid media to precipitate protein and to extract the iron, a procedure which was introduced by Barkan (1927). Some workers use heat to assist liberation of the iron, but others omit this. Methods involving wet ashing for determining total iron have been used to some extent but are tedious and timeconsuming. Recently, Webster (1960) introduced a rapid method which omits protein precipitation but involves heating with a detergent. In nearly all cases the iron is complexed with thiocyanate, $a, a^{\prime}-$ dipyridyl, $o$-phenanthroline, bathophenanthroline or its sulphonate, and measured colorimetrically.

Most methods for the determination of latent iron-binding capacity depend on the small increase in light absorption at about $520 \mathrm{~m} \mu$ when ferrous

Received for publication 29 November 1960. iron is added to the serum, either incrementally or in. excess (Rath and Finch, 1949; Cartwright andD Wintrobe, 1949; Ventura, 1952; Kaldor, 1955). Thes disadvantage of this kind of method is its low sensitivity, although some variations are simply and rapidly performed. In another type of method, excess $\mathbb{D}_{\overparen{D}}$ iron is added to saturate the transferrin, the residual iron being removed by first complexing with $o$ - 을 phenanthroline. Strong acids are then added tor liberate the serum-bound iron but not that como plexed to $o$-phenanthroline, the latter being precipi tated along with the serum proteins. A frequento problem with this type of method is the difficulty in obtaining an optically clear protein-free filtrate of supernatant; this is essential to the success of the method as even slight amounts of turbidity lead to erroneous results; the use of bathophenanthroline or its sulphate would reduce these errors some $\frac{D}{8}$ what by increasing the ratio of colour to turbidity but they would remain appreciable. Several blanksల are required and the procedure is somewhat pro tracted.

The objectives of the present work were to developw rapid direct methods which avoid precipitation of proteins and heating, and require only small volumeso of serum and simple blanks. The procedures to bed described are carried out entirely in the optical cells? or tubes used for the light absorption measurements, each determination requiring $0.5 \mathrm{ml}$. serum iP bathophenanthroline or its sulphonate (Case, $1951 \AA$ Peterson, 1953; Trinder, 1956) is used, or $1 \mathrm{ml}$. i $\not 2$ $o$-phenanthroline is used as complexing agent. 
METHOD I:

SERUM TRANSFERRIN IRON DETERMINATION

PREPARATION OF GLASSWARE All glassware is completely wetted internally with the acid cleaning mixture described below and then washed in tap water and finally ion-free water. Apparatus is stored away from dust. Apart from the optical cells and serum pipettes, rinsing of glassware with ion-free water after use is all that is required.

COLLECTION OF BLOOD An iron-free syringe with a new needle is satisfactory. Specimens may be collected at any time, but where possible, early morning ones from fasting donors are preferable. The blood is stored in an iron-free tube. Plasma is unsatisfactory for the methods described.

REAGENTS These were made up as follows:-

Heated sodium dithionite $3 \%$ in $0.1 \mathrm{M}$ sodium acetate Dissolve the solid in the acetate solution and heat about $20 \mathrm{ml}$. solution for five minutes in a boiling water bath. Cool the solution to room temperature. Use fresh preparations each day. (For determinations with o-phenanthroline the same reagent is used.)

Sulphonated bathophenanthroline, 04\% To $200 \mathrm{mg}$. bathophenanthroline in a hard-glass boiling tube add 1 $\mathrm{ml}$. chlorsulphonic acid and boil the contents gently over a small flame for 30 seconds. Cool the tube to room temperature and cautiously add $10 \mathrm{ml}$. iron-free water, followed by $6.5 \mathrm{ml} .5 \mathrm{~N}$ sodium hydroxide. Mix and heat in boiling water for a few minutes until a clear solution is obtained. Cool to room temperature and adjust the $p H$ to 8 to 12 units. Add $0.5 \mathrm{ml}$. glacial acetic acid and mix. The $p \mathrm{H}$ should then be 4 to 5 units. Dilute to $50 \mathrm{ml}$. with iron-free water. Add a few drops of chloroform and keep the reagent refrigerated. This reagent is a modification of that described by Trinder (1956).

o-Phenanthroline, $0.25 \%$ Dissolve $125 \mathrm{mg}$. hydrated solid in $2.5 \mathrm{ml}$. alcohol and some water and dilute to $50 \mathrm{ml}$. (This reagent is an alternative to the preceding one.)

Standard iron solution, $0.5 \mathrm{mg}$. Fe $/ \mathrm{ml}$. Dissolve $0.3511 \mathrm{~g}$. ferrous ammonium sulphate hexahydrate, A.R., in $0 \cdot 1 \mathrm{~N}$ sulphuric acid (iron-free) and dilute to $100 \mathrm{ml}$. with this acid. This reagent is stable in total iron for a long time, although ferric ions slowly accumulate by aerial oxidation.

Standard iron solutions (dilute) Prepare a $100 \mathrm{ml}$. volumetric flask as follows. Treat the flask with the acid cleaning solution described below and wash thoroughly with tap water. Wet the whole of the inside of the flask with $2 \%$ aqueous cetyl trimethylammonium bromide (Cetavlon), wash thoroughly, and rinse with ion-free water. The detergent coats the glass and inhibits adsorption of iron. (If the detergent treatment was omitted it was found that the weak standards deteriorated with time.)

Measure 5 or $10 \mathrm{ml}$. stronger iron standard into the flask, add about $10 \mathrm{mg}$. ascorbic acid and dilute to the mark with iron-free water. These standards contain 25 or $50 \mu \mathrm{g}$. Fe/ml. respectively. The weaker one is used with bathophenanthroline or its sulphonate. Prepare them freshly about once a fortnight. Under these conditions all the iron is in the ferrous state.

Acid cleaning solution Dissolve about $100 \mathrm{mg}$. potassium permanganate in $200 \mathrm{ml}$. cold concentrated sulphuric acid. On no account should heat be applied because of the risk of explosive decomposition; the cold solution has been used for many years by one of us. Glassware is cleaned in the usual way and drained as free as possible of surplus water before treatment with this reagent, which may be returned subsequently to the stock bottle and used until exhausted, as shown by the precipitation of manganese dioxide. Any manganese dioxide stain is removed with ease by treating it with dilute sulphuric acid containing a little hydrogen peroxide.

PROCEDURE WITH BATHOPHENANTHROLINE SULPHONATE Wash two optical cells $(1 \mathrm{~cm}$. light path) with soap solution and a small plug of cotton wool wound round the end of a thin wooden stick. Rinse thoroughly, drain, and inspect the cells for freedom from visible organic matter; then fill them with the acid cleaning mixture. Return the acid to its container and thoroughly wash the cells, rinsing finally with ion-free water. Drain on to filter paper and wipe the outsides with soft tissue.

Into cell B (for blank) measure $1.75 \mathrm{ml}$. water and into cell $\mathrm{T}$ (for test) $0.5 \mathrm{ml}$. serum. To each add $0.75 \mathrm{ml}$. heated dithionite reagent. Mix the contents of cell $\mathrm{T}$ by gentle but thorough oscillation of the forefinger against the lower side of the cell. After four minutes add $1.25 \mathrm{ml}$. water to cell $\mathrm{T}$ and mix the contents of both $\mathrm{B}$ and $\mathrm{T}$ by up-anddown stirring with a thin glass rod flattened at the bottom; avoid the optical faces of the cells. Alternatively, mix with a Pasteur pipette. Read T against B in a spectrophotometer at $534 \mathrm{~m} \mu$, the wavelength of maximum absorption of the iron-(bathophenanthrolene sulphonate) complex. Let the reading be $A_{1}$ units (linear absorbance or meter scale divisions). To $T$ and $B$ add $0.08 \mathrm{ml}$. bathophenanthroline sulphonate reagent by means of a $0.2 \mathrm{ml}$. pipette and mix. After two minutes read again in the instrument; let the reading be $A_{2}$ units. To $T$ only add $0.04 \mathrm{ml}$. (1 $\mu \mathrm{g}$.) standard iron $25 \mu \mathrm{g} . / \mathrm{ml}$. by means of a $0.1 \mathrm{ml}$. pipette. Mix and after one minute again read $\mathrm{T}$ against $B$. Let the third reading be $A_{3}$ units. Throughout the procedure it is best not to remove the cells from their holder in order to avoid errors. If a cell should be removed, replace it with the same optical face towards the detector of the instrument. When the measurements are carried out as described, the absorbance readings are relative to one cell only and accordingly the results are not affected by differences in cell characteristics. Consequently it is not absolutely necessary to use high quality optical glassware; in fact it should be poss:ble to use any optically clear container such as a test tute, although this has not been investigated in the present work.

PROCEDURE WITH $O$-PHENANTHROLINE The procedure is much the same as before, the following volumes being used at each successive step:

(a) $1 \mathrm{ml}$. water in cell $\mathrm{B} ; 1 \mathrm{ml}$. serum in cell $\mathrm{T}$

(b) $1.5 \mathrm{ml}$. heated dithionite $3 \%$ reagent in each 
(c) $0.08 \mathrm{ml} . o$-phenanthroline reagent in each

(d) $0.04 \mathrm{ml}$. (2 $\mu \mathrm{g}$.) standard iron, $50 \mu \mathrm{g}$. $/ \mathrm{ml}$. in T only

Readings in this case are made at $510 \mathrm{~m} \mu$, the wavelength of maximum absorption of the iron-(o-phenanthroline) ${ }_{3}$ complex.

Calculation This is the same for both colour reagents. Ignoring volume changes:

Increment in linear absorbance on addition of standard iron $=\mathbf{A}_{3}-\mathbf{A}_{2}$

Increment due to liberated serum iron $=A_{2}-A_{1}$

So that $\mu \mathrm{g}$. iron in $1 \mathrm{ml}$. serum $=\frac{A_{2}-A_{1}}{\bar{A}_{3}-A_{2}} \times 2$

and so, serum iron $=\frac{A_{2}-A_{1}}{A_{3}-A_{2}} \times 200 \mu \mathrm{g} . \%$

If allowance is made for dilution factors to compensate for volume changes, the exact calculation is:

Transferrin iron $=\frac{1.03 \mathrm{~A}_{2}-\mathrm{A}_{1}}{1.05 \mathrm{~A}_{3}-1.03 \mathrm{~A}_{2}} \times 200 \mu \mathrm{g} . \%$

However, the error in using the approximate formula is usually less than $2 \mu \mathrm{g} . \% \mathrm{Fe}$ and may be ignored for most purposes. For low values the more exact equation is preferred.

METHOD II:

DETERMINATION OF LATENT IRON-BINDING CAPACITY

The preparative steps are the same as for serum iron determination.

REAGENTS These are as for the previous method, with one addition:

Normal saline-ascorbic acid Dissolve a knife-point (N $10 \mathrm{mg}$.) of ascorbic acid in $50 \mathrm{ml}$. normal saline. It is essential that the reagent be made under iron-free conditions, i.e., using clean glassware, pure sodium chloride, and de-ionized water. No colour should be visible on addition of bathophenanthroline or its sulphonate.

PROCEDURE WITH BATHOPHENANTHROLINE Into cell B measure $0.58 \mathrm{ml}$. de-ionized water and $2 \mathrm{ml}$. salineascorbic acid reagent, and into $T$ measure $0.5 \mathrm{ml}$. serum and $2 \mathrm{ml}$. saline-ascorbic acid. To T only, add $0.08 \mathrm{ml}$. (2 $\mu \mathrm{g}$.) standard iron $25 \mu \mathrm{g}$. $/ \mathrm{ml}$. and mix the contents of both cells. After two minutes read as before at $534 \mathrm{~m} \mu$. Let the reading be $A_{4}$ units. Within three minutes from the time of adding the iron, add to both $B$ and $T 0.08 \mathrm{ml}$. bathophenanthroline reagent and, after mixing, allow the solutions to stand for six minutes. Read again and check after further two-minute intervals. No further increase is usually observed after eight to 10 minutes. Let this reading be $A_{5}$ units. Finally, add $0.04 \mathrm{ml}$. $(1 \mu \mathrm{g}$.) standard iron, $25 \mu \mathrm{g} . / \mathrm{ml}$., to $\mathrm{T}$ only; mix, and after one minute read as before. Let this final reading be $A_{6}$.

PROCEDURE WITH $O$-PHENANTHROLINE If this reagent is used the volumes and procedures are modified as follows:

(a) To B add $1.08 \mathrm{ml}$. water and $1.5 \mathrm{ml}$. saline-ascorbic acid; and to T add $1 \mathrm{ml}$. serum and $1.5 \mathrm{ml}$. saline-ascorbic acid; mix.

(b) To T only add $0.08 \mathrm{ml}$. (4 $4 \mu \mathrm{g}$.) standard iron, 50 $\mu \mathrm{g} . / \mathrm{ml}$. and proceed as before. (c) Add $0.08 \mathrm{ml}$. o-phenanthroline reagent to both cells, $\stackrel{\overrightarrow{\mathrm{o}}}{\text { ․ }}$ and in this case allow the solutions to stand for 10 to 20 minutes until a constant reading is achieved.

(d) To T add $0.04 \mathrm{ml}$. (2 $\mu \mathrm{g}$.) standard iron, $50 \mu \mathrm{g} . / \mathrm{ml}$., mix, and proceed as before.

All readings are made at $510 \mathrm{~m} \mu$ for this reagent.

CALCulation This is the same for either colour reagent and is carried out as follows:

Calculated absorbance from added iron if none were $\vec{\circ}$ bound to transferrin $=2\left(A_{6}-A_{5}\right)$

Measured absorbance of residual iron complex $=\vec{\omega}$ $\mathrm{A}_{5}-\mathrm{A}_{4}$

Therefore absorbance of complex which would have been produced by the amount of added iron bound by transferrin

$=2\left(A_{6}-A_{5}\right)-\left(A_{5}-A_{4}\right)$

Iron taken up by transferrin in $1 \mathrm{ml}$. serum

$$
=\frac{\left.2\left(A_{6}-A_{5}\right)-A_{5}-A_{4}\right)}{A_{6}-A_{5}} \times 2 \mu \mathrm{g} .
$$

Latent iron-binding capacity

$$
=\frac{2\left(A_{6}-A_{5}\right)-\left(A_{5}-A_{4}\right)}{A_{6}-A_{5}} \times 200 \mu \mathrm{g} . \%
$$

As before, the exact expression is: Latent iron-binding capacity

$$
=\frac{2\left(1.05 \mathrm{~A}_{6}-1.03 \mathrm{~A}_{5}\right)-\left(1.03 \mathrm{~A}_{5}-\mathrm{A}_{4}\right)}{1.05 \mathrm{~A}_{6}-1.03 \mathrm{~A}_{5}} \times 200 \mu \mathrm{g} . \% \frac{\overrightarrow{\mathscr{Q}}}{\vec{P}}
$$

but again the error involved in the use of observed linear. absorbances is usually small, except for low values of the latent iron-binding capacity when the last expression should be used. It can be shown also that the error in the approximate expression may be larger for clear sera than for those with a higher background absorption.

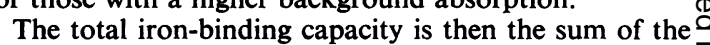
unsaturated transferrin iron level $\left(\mathrm{TFe}_{\mathrm{u}}\right)$ and the latent $\overline{\mathrm{O}}$ iron-binding capacity.

Total iron-binding capacity $=\mathrm{TFe}_{\mathrm{u}}+$ latent ironbinding capacity, and the percentage saturation is given by:

$$
\text { Saturation }=\frac{\mathrm{TFe}_{\mathrm{u}}}{\text { Total iron-binding capacity }} \times 100 \%
$$

EXPERIMENTAL RESULTS

RECOVERY EXPERIMENTS A few general remarks are necessary concerning the nature of the iron which is being determined. For analytical purposes the iron $\bar{N}$ in natural serum may be considered to consist of $(a)$. transferrin iron, extractable with heated dithionite; 0 (b) non-specific iron, also extractable; and (c) other iron, not extractable with dithionite reagent. Hence 0 method I will determine $(a)$ and $(b)$ only.

When iron is added incrementally to serum, the $\frac{\mathscr{C}}{\varnothing}$ following effects are observed. Amounts less than $\stackrel{?}{-}$ those required to saturate the transferrin are taken 0 up virtually quantitatively by the transferrin, and no움 significant increase in absorbance at $534 \mathrm{~m} \mu$ is $\stackrel{\mathbb{D}}{\Omega}$ observed when bathophenanthroline sulphonate is $\mathbb{D}$ 
added to such sera after dilution with saline-ascorbic acid, indicating no non-specific uptake.

When amounts of iron more than those necessary to saturate the transferrin component are added, some of the excess iron is non-specifically absorbed, as evidenced by a rise in linear absorbance at 534 $\mathrm{m} \mu$ when bathophenanthroline sulphonate is added to the diluted sera. This indicates that while bathophenanthroline sulphonate in saline-ascorbic acid has no effect on transferrin-bound iron it is a stronger complexing agent than non-specific centres in the serum and, under our conditions at least, fairly rapidly chelates all such iron. Further, if excess iron is added to serum and non-specific uptake allowed to proceed for 10 minutes, then all the added iron is recoverable, i.e., is dithionite extractable. The conclusion from these observations is that the iron measured by methods I and II is of types $(a)$ and $(b)$. Further, natural serum contains no iron of type $(b)$. Since analyses for total iron by a wet-ashing procedure have not been carried out in the present work, the magnitude of $(c)$ remains unknown. Methods employing strong acid extraction might be expected to give results nearer to those obtained by wetashing procedures and, if type (c) iron is present, higher than those obtained by our method I. The results of various workers are compared later (see under Normal Values). As regards the values found by method II, the above observations and the recovery experiments show that this method finally measures only iron taken up by the unsaturated transferrin component of the serum, that is, type (a) iron.

Recovery experiments were carried out in order to test the potentiality of both methods. Having determined the serum iron and latent iron-binding capacity values of a number of sera, amounts of iron both less than and more than those required to saturate the transferrin were added to the sera, which were then analysed as before. Table I presents some typical results obtained by method I for four
TABLE I

RECOVERIES OF IRON ADDED TO SERA USING METHOD I

\begin{tabular}{ccccc}
$\begin{array}{l}\text { Sample } \\
\text { No. }\end{array}$ & $\begin{array}{l}F e \\
(\mu g . \%)\end{array}$ & $\begin{array}{l}\text { Added Fe } \\
(\mu g . \%)\end{array}$ & $\begin{array}{l}\text { Recovered Fe } \\
(\mu g . \%)\end{array}$ & $\begin{array}{l}\text { Percentage } \\
\text { Recovery }\end{array}$ \\
\hline $1^{1}$ & 27 & 0 & & \\
& 121 & 100 & 94 & 94 \\
& 149 & 125 & 122 & 98 \\
& 177 & 150 & 150 & 100 \\
2 & 39 & 0 & & \\
& 139 & 100 & 100 & 100 \\
& 182 & 150 & 143 & 95 \\
3 & 84 & 0 & & \\
& 191 & 100 & 107 & 107 \\
4 & 62 & 0 & & \\
& 155 & 100 & 93 & 93 \\
52 & 32 & 0 & & 106 \\
& 138 & 100 & 106 &
\end{tabular}

Mean recovery $=99 \cdot 3 \pm 7 \%$

1o-phenanthroline reagent was used for samples 1 to 4 .

'This serum had a latent iron-binding capacity of $97 \mu \mathrm{g}$. \%: bathophenanthroline reagent was used.

sera which were undersaturated; the fifth was fully saturated as regards the transferrin component and partially saturated as regards the non-specific components. In all cases, quantitative recovery of the added iron was obtained, whether this was of type $(a)$ or of types $(a)$ and $(b)$ together. None of the added iron is converted to the irrecoverable type $(c)$.

Similar 'recoveries' were carried out by method II. In this case the decrease in the latent iron-binding capacity was measured after undersaturating with $100 \mu \mathrm{g} . \% \mathrm{Fe}$. A typical experiment is shown in Table II. The latent iron-binding capacity was determined in duplicate on the original serum and in triplicate on the serum with added iron.

Such experiments showed that the uptake of iron by transferrin and the recovery of residual ionic iron are virtually quantitative under the conditions described.

TABLE II

TYPICAL 'RECOVERY' EXPERIMENT BY METHOD II ${ }^{1}$

\begin{tabular}{|c|c|c|c|c|c|c|c|c|c|c|c|}
\hline \multirow[t]{2}{*}{ Serum } & \multicolumn{9}{|c|}{ Absorbance Readings $(A)$} & \multirow{2}{*}{$\begin{array}{l}\text { Latent Iron- } \\
\text { binding Capacity } \\
(\mu \mathrm{g} . \%)\end{array}$} & \multirow[t]{2}{*}{ Mean ( $\mu g$. } \\
\hline & $A_{4}$ & $A_{5}$ & A. & $A_{4}$ & $A_{5}$ & $A_{6}$ & $A_{4}$ & $A_{5}$ & $A_{6}$ & & \\
\hline Original & $\begin{array}{r}0 \cdot 156 \\
\Delta 0 \cdot 148\end{array}$ & $\begin{array}{l}0.304 \\
0.146\end{array}$ & 0.450 & $\begin{array}{r}0 \cdot 154 \\
\Delta 0 \cdot 148\end{array}$ & $\begin{array}{l}0 \cdot 302 \\
0 \cdot 146\end{array}$ & 0.448 & & & & $\begin{array}{l}197 \cdot 3 \\
197 \cdot 3\end{array}$ & $197 \cdot 3$ \\
\hline Plus $100 \mu \mathrm{g} . \% \mathrm{Fe}$ & $\begin{array}{r}0.157 \\
\Delta 0 \cdot 217\end{array}$ & $\begin{array}{l}0.374 \\
0.145\end{array}$ & 0.519 & $\begin{array}{r}0.161 \\
\Delta 0.216\end{array}$ & $\begin{array}{l}0.377 \\
0.145\end{array}$ & 0.522 & $\begin{array}{r}0.156 \\
\Delta 0.220\end{array}$ & $\begin{array}{l}0.376 \\
0.144\end{array}$ & 0.520 & $\begin{array}{r}100 \cdot 7 \\
102 \cdot 1 \\
96 \cdot 6\end{array}$ & $99 \cdot 8$ \\
\hline
\end{tabular}

Difference between means $=97.5 \mu \mathrm{g} . \%$; expected difference $=100 \mu \mathrm{g} . \%$

${ }^{1}$ Bathophenanthroline reagent was used for these experiments. 
TABLE III

REPRODUCIBILITY OF RESULTS FOR SERUM IRON AND LATENT IRON-BINDING CAPACITY

Serum No. Colour Reagent

Serum Iron ( $\mu \mathrm{g} . \%)$

Latent Iron-binding Capacity (ug. \%)

\begin{tabular}{|c|c|c|c|c|c|c|c|c|}
\hline & & & & & \\
\hline & & & & & Mean & & & Mean \\
\hline 1 & $\begin{array}{l}\text { Sulphonated bathophenanthroline } \\
o \text {-phenanthroline }\end{array}$ & $\begin{array}{l}31 \cdot 5 \\
33 \cdot 3\end{array}$ & $\begin{array}{l}31 \cdot 5 \\
32 \cdot 0\end{array}$ & $34 \cdot 2$ & $\begin{array}{l}32 \cdot 3 \\
32 \cdot 7\end{array}$ & $\begin{array}{l}240 \cdot 5 \\
240 \cdot 6\end{array}$ & $\begin{array}{l}240 \cdot 3 \\
239 \cdot 4\end{array}$ & $\begin{array}{l}240 \cdot 4 \\
240 \cdot 0\end{array}$ \\
\hline 2 & $o$-phenanthroline & $52 \cdot 6$ & $56 \cdot 4$ & $57 \cdot 7$ & $55 \cdot 6$ & & & \\
\hline 3 & $o$-phenanthroline & $83 \cdot 3$ & $84 \cdot 6$ & $84 \cdot 6$ & $84 \cdot 2$ & & & \\
\hline
\end{tabular}

REPRODUCIBILITY Table III summarizes some typical results obtained from concurrent triplicate or duplicate analyses of the same serum. The reproducibility is reasonably satisfactory for either colour reagent; furthermore, the results obtained when the same serum is analysed with each reagent in turn are normally in good accord.

The standard deviation from the mean for serum iron values is $\pm 3.3 \%$ so that the extreme confidence limits may be set at $\pm 10 \%$ (Henry and Segalove, 1952).

The variations in latent iron-binding values for duplicate or triplicate determinations lie within $\pm 3 \%$ of the mean as compared with a variation from the mean of $\pm 6 \%$ for serum iron duplicates or triplicates, so that for determinations of the latent iron-binding capacity the extreme confidence limits of variation may be set at about $\pm 5 \%$ of the mean value.

In both methods I and II the increases in absorbance on addition of standard iron in the last step of the determinations show little variation, so much so, that any marked deviation from the mean increment may be usually regarded as due to deterioration of the iron standards or to a pipetting error. The values appear to be little affected by the particular serum used. For a fresh standard we find that the increment does not vaty by more than 0.003 linear absorbance units under the best conditions.

EFFECTS OF HAEMOLYSIS AND TURBIDITY It has been stated by some authors (e.g., Webster, 1960) that dithionite will release iron from haemoglobin and falsify any measurement of serum iron. This point was investigated. A blood sample containing 13.2 g./100 ml. haemoglobin was diluted $1: 100$ with water and centrifuged. Varying amounts of the supernatant were added to a serum and the serum iron determined by method I. Identical results were obtained up to a level of about $0.3 \%$ haemolysis indicating that no haemoglobin iron is released under our conditions. Beyond this level precipitation occurred and rendered the results erratic. Sera which on are obviously haemolysed should therefore be rejected as unsuitable for analysis. Similar results were obtained for determinations of latent iron-binding capacity.

It was found that slightly turbid sera could be analysed satisfactorily, providing the finally observed linear absorbances $A_{3}$ and $A_{6}$ fell below 0.8 units when using the bathophenanthroline reagent for both methods I and II. Above this reading, erratic results were obtained when a clear serum was compared with the same serum rendered turbid by addition of varying amounts of cholesterol in olive oil. In practice, moderate degrees of turbidity can thus be tolerated, but the methods will not deal satisfactorily with markedly lipaemic sera. A possibly more accurate procedure for method II is to replace the aqueous blank with a serum blank, when turbidity effects should cancel, providing the cells $B$ and $\mathrm{T}$ are closely matched and of good optical quality.

EFFECTS OF AGEING AND TEMPERATURE ON SERUM A number of sera were analysed by methods I and II over periods ranging up to 140 hours from the time of taking the blood specimens. No appreciable change in values occurred for sera up to 24 hours' old which were left at room temperature. For sera refrigerated at $5^{\circ}$ to $8^{\circ}$ variable results were obtained, but in general somewhat lower values were found for both iron levels and latent iron-binding capacities. As the sera aged further, generally lower values were obtained and the results of triplicate analyses for serum iron became more and more erratic with refrigerated specimens. After 140 hours marked decreases and eccentricity in values for latent ironbinding capacity were observed, these being even greater with refrigerated sera. No advantage was found in warming refrigerated specimens to $37^{\circ} \mathrm{C}$. for 30 minutes. It is recommended therefore that specimens should be examined as soon as possible, in any case within 30 hours, refrigeration being contraindicated. 
VARIATIONS IN THE NATURE OF THE EXTRACTOR IN METHOD I Sodium thiosulphate, potassium metabisulphite, hydrazine hydrate, sodium sulphite, sodium thiolacetate, and sodium dithionite were investigated at various concentrations in order to assess their powers of extracting and concomitantly reducing the transferrin iron in both fresh and aged serum. Sodium dithionite was much superior to the others as regards spzed and efficiency of extraction and was selected as the most suitable reagent. It was then found that even fresh solutions of sodium dithionite in stabilizing acetate were incapable of extracting all the transferrin iron from sera which had aged for 24 hours or more. However, if the fresh dithionite-acetate solution was heated for five minutes in boiling water, the resultant solution was fully capable of extracting the iron from samples up to 30 hours old but not beyond that age. The nature of the extractor is not known. Sodium dithionite solutions are said to break down to a mixture of thiosulphate and metabisulphite in the absence of oxygen, or to sodium metabisulphite in the presence of oxygen (Partington, 1937). However, a mixture of equal volumes of sodium metabisulphite $6 \%$ and sodium thiosulphate $8 \%$ failed to extract iron completely within a period of 10 minutes. The mixture on heating behaved in a similar fashion to dithionite in that it turned yellow at $100^{\circ}$ and became colourless on cooling to room temperature; but once again, the mixture failed to yield a full recovery of the serum iron. Likewise, a heated mixture of solutions of sodium metabisulphite and yellow ammonium sulphide, adjusted to $p \mathrm{H} 4$ with acetic acid, extracted but little iron. Although sodium dithionite is not the ideal compound to use, as it is frequently impure and contains variable amounts of iron, no suitable alternative could be discovered. The material employed (B.D.H. laboratory reagent grade) was fairly satisfactory as regards iron content and gave acceptably low blanks (corresponding to about $0.1 \mu \mathrm{g}$. Fe per $0.75 \mathrm{ml}$. reagent).

Ascorbic acid in low concentration appears to have no effect on bound transferrin iron, so that in method II it is an ideal compound for the reduction of free ionic iron without disturbing the binding of transferrin iron.

NORMAL VAlues Sera from 12 males and 14 females were examined by methods I and II using $o$ phenanthroline as colour reagent. The subjects were active blood donors with normal haemoglobin levels. The number of donations given previously varied from 0 to 41 and these were usually made at threemonthly intervals. If any subject who had made more than six previous donations had a serum iron level or a latent iron-binding capacity outside the normal ranges found by previous workers, these values were rejected. Data from analyses of the sera of new donors were included, whatever their values. The findings are presented in Table IV. The ages of the donors ranged from 18 to 60 years. No attempt was made to investigate any possibility of diurnal variation in serum iron levels, all specimens having been collected between 9 and 11.30 a.m. from nonfasting donors. (No serum had to be rejected becaus? of too great a turbidity.) Neither was any investigation made of possible variations in levels in female subjects at various stages of the menstrual cycle.

Compared with the results of previous workers (see Davies, Levin, and Oberholzer, 1952, for a

TABLE IV

NORMAL VALUES FOR SERUM TRANSFERRIN IRON AND IRON-BINDING CAPACITY

Males

\begin{tabular}{llllll}
\hline No. Age & $\begin{array}{l}\text { Previous } \\
\text { Donations }\end{array}$ & $\begin{array}{l}\text { Serum } \\
\mathrm{Fe} \\
(\mu \mathrm{g.} \%)\end{array}$ & $\begin{array}{l}\text { Latent } \\
\text { Iron- } \\
\text { binding } \\
\text { Capacity } \\
(\mu \mathrm{g.} \%)\end{array}$ & $\begin{array}{l}\text { Total } \\
\text { Iron- } \\
\text { binding } \\
\text { Capacity } \\
(\mu \mathrm{g.} \%)\end{array}$ & $\begin{array}{l}\text { Saturation } \\
\text { Sal }\end{array}$ \\
\hline
\end{tabular}

\begin{tabular}{ll}
\hline 1 & 43 \\
2 & 23 \\
3 & 22 \\
4 & 38 \\
5 & 32 \\
6 & 38 \\
7 & 32 \\
8 & 24 \\
9 & 20 \\
10 & 58 \\
11 & 32 \\
12 & 37 \\
Means \\
Ranges
\end{tabular}

0
3
0
$1 ?$
1
20
30
$1 ?$
5
41
4
0

$\begin{array}{rccr}140 & 156 & 296 & 47 \\ 78 & 199 & 277 & 28 \\ 106 & 165 & 271 & 39 \\ 150 & 303 & 453 & 33 \\ 83 & 195 & 278 & 30 \\ 76 & 174 & 250 & 30 \\ 114 & 200 & 314 & 36 \\ 104 & 155 & 259 & 40 \\ 147 & 104 & 251 & 59 \\ 160 & 115 & 275 & 58 \\ 63 & 151 & 214 & 29 \\ 84 & 151 & 235 & 36 \\ 109 & 172 & 281 & 39 \\ 63-160 & 104-303 & 214-453 & 28-5\end{array}$

Females

\begin{tabular}{ccccccc}
\hline No. & Age & $\begin{array}{l}\text { Previous } \\
\text { Donations }\end{array}$ & $\begin{array}{l}\text { Serum } \\
\text { Fe } \\
(\mu g . \%)\end{array}$ & $\begin{array}{l}\text { Latent } \\
\text { Iron- } \\
\text { binding } \\
\text { Capacity } \\
(\mu g . \%)\end{array}$ & $\begin{array}{l}\text { Total } \\
\text { Iron- } \\
\text { binding } \\
\text { Capacity } \\
(\mu g . \%)\end{array}$ & $\begin{array}{l}\% \\
\text { Saturation }\end{array}$ \\
\hline 1 & 19 & 2 & 88 & 183 & 271 & 32 \\
2 & 44 & 0 & 92 & 146 & 238 & 39 \\
3 & 21 & 0 & 142 & 209 & 351 & 41 \\
4 & 21 & 5 & 77 & 259 & 336 & 23 \\
5 & 31 & 0 & 27 & 175 & 202 & 13 \\
6 & 39 & 4 & 94 & 127 & 221 & 43 \\
7 & 20 & 5 & 109 & 116 & 225 & 48 \\
8 & 18 & 0 & 39 & 158 & 197 & 20 \\
9 & 60 & 17 & 84 & 164 & 248 & 34 \\
10 & 34 & 3 & 50 & 217 & 267 & 19 \\
11 & 23 & 0 & 96 & 136 & 232 & 41 \\
12 & 49 & 1 & 92 & 180 & 272 & 34 \\
13 & 35 & - & 94 & 187 & 281 & 33 \\
14 & 20 & - & 62 & 164 & 226 & 27 \\
Means & & 82 & 173 & 255 & 32 \\
Ranges & & $27-142$ & $116-259$ & $197-351$ & $13-48$
\end{tabular}


summary) our values for serum iron levels are somewhat lower in male subjects and decidedly lower for females. Since the values previously found have nearly all been based on precipitation methods with strong acid extraction procedures, it would appear that such methods come closer to determining total serum iron than the present ones, which probably give more nearly a measure of the iron bound to transferrin only. Our markedly lower mean value for females might indicate that a higher proportion of the serum iron is of type (c) than is the case for males. All workers, with the possible exception of Cartwright and Wintrobe (1949), find lower values for females than for males, the differences ranging from 12 to $27 \mu \mathrm{g}$. Fe \% (including the present findings).

Again, as regards latent iron-binding capacity levels, our results fall below those previously obtained. With methods such as those of Rath and Finch (1949), the increments in linear absorbance are relatively small and errors of unknown magnitude may occur, particularly with sera containing any turbidity; little seems to have been published concerning confidence limits for this type of method so that comparisons with the present one are difficult to make. For females, the mean values by both methods are considerably lower than those of other authors. For males, however, other values are similar to those of Rath and Finch (1949).

In spite of the discrepancies between the normal values published for serum iron, and latent and total iron-binding capacity levels, the figures for percentage saturation found by all workers are in tolerably good accord, being $38 \pm 4 \%$ for males and $33 \pm 1 \%$ for females. A comparative study of the various methods is evidently needed.

\section{DISCUSSION}

The method described for serum iron determination is based on the series of reactions:

$$
\mathrm{TFe}_{\mathrm{u}} \underset{\mathrm{Na}_{2} \mathrm{~S}_{2} \mathrm{O}_{4}}{\stackrel{\text { heated }}{\longrightarrow}} \mathrm{T}+\mathrm{Fe}^{2+} \underset{\text { phen }}{\longrightarrow} \mathrm{Fe}(\text { phen })_{3}
$$

The success of the method depends on two main requisites. First, the transferrin iron must be completely removed and reduced to the ferrous state; the recovery experiments indicated that such is the case. Secondly the background absorption due to turbidity and serum chromogens must remain stable throughout the procedure. This was checked with a number of sera by running the absorption spectra on a recording spectrophotometer at each stage of method I, beginning at wavelengths higher than those at which the iron complex absorbs. Coinci- - 을 dence of the spectra in this region $(700$ to $660 \mathrm{~m} \mu) \underset{\overrightarrow{2}}{\overrightarrow{2}}$ was usually observed, any deviations being of a minor order, little more than would be expected as $\frac{}{\circ}$ the result of the dilution effect of added reagents. The reasonable assumption could then be made $\widetilde{\widetilde{ }}$ that the background absorption at $540 \mathrm{~m} \mu$ likewise was unaltered to any extent. Again, substantiallyes constant and quantitative recoveries of added iron $\vec{\circ}$ would indicate that no serious fluctuations in back- $-\overrightarrow{-}$ ground occur at any stage, so that the method may. be used with confidence.

Method II, for the determination of the latent iron-? binding capacity of serum, is based on the following $\vec{f}$ scheme:

(a) $\mathrm{P}+\mathrm{TFe}_{\mathrm{u}}+\mathrm{Fe}_{\mathrm{A}}^{2+} \longrightarrow \mathrm{TFe}_{\text {sat. }}+\mathrm{PFe}_{\mathrm{p}}+\mathrm{Fe}_{\mathrm{R}}^{2,}+\stackrel{+\infty}{\infty}$

(d) $\mathrm{Fe}_{\mathrm{R}}$ (phen $)_{3}=\mathrm{Fe}_{\mathrm{R}^{\prime}}$ (phen $)_{3}+\mathrm{Fe}_{\mathrm{p}}$ (phen $)_{3}$ where:

$\mathbf{P}=$ non-transferrin proteins or serum con- $\vec{c}$ stituents

$\mathrm{TFe}_{\mathbf{u}}=$ transferrin in original serum

$\mathrm{TFe}_{\text {sat. }}$ = saturated transferrin component

$\mathrm{Fe}^{2+}=$ added iron

$\mathrm{PFe}_{\mathrm{p}}=$ unsaturated non-specific iron com-

$\mathrm{Fe}_{\mathrm{p}}(\text { phen })_{3}=$ iron complex formed from non specifically bound iron

$\mathrm{Fe}_{\mathrm{R}^{\prime}}^{2+}=$ added ionic iron not bound to $\mathrm{T}$ or $\mathrm{P}^{\lessgtr}$

$\mathrm{Fe}_{\mathrm{R}}=$ total residual added iron not bound to transferrin, after establishment of equilibrium

For the method to be successful, the following ideal conditions must be fulfilled as closely aspossible: (1) As before, background should be un altered; (2) the complexing agent should completely remove non-specifically bound iron (scheme, parf (b)); (3) the complexing agent should not affect thes transferrin-bound iron; (4) the reducing agent used. to keep ionic iron in the ferrous state should not liberate transferrin-bound iron.

Condition (1) was investigated spectrophoto 0 metrically as for method I. Small departures from background constancy were noted in some cases? somewhat larger than for method I, but no way could be found of allowing successfully for these change apart from including a serum blank. For the majority of sera, however, variations are small and consistento for any one serum as judged by the high reproducio bility obtainable with replicate determinations. Fo larger variations possible errors are difficult to 
estimate, since any change in background absorbance at $540 \mathrm{~m} \mu$ remains occult.

Conditions (2), (3), and (4) have been discussed already and appear to be closely obeyed when the procedure described is followed. For the majority of sera, therefore, it appears that method II gives a reasonably reliable determination of the latent ironbinding capacity.

We wish to thank Dr. R. J. Walsh and Mrs. R. Pepper, of the Red Cross Blood Transfusion Service, New South Wales, for their unfailing and willing cooperation in arranging a supply of blood specimens.

This work is published with the approval of the Director General, Department of Public Health, New South Wales.

\section{REFERENCES}

Barkan, G. (1927). Hoppe-Seylers Z. physiol. Chem., 171, 194.

Cartwright, G. E., and Wintrobe, M. M. (1949). J. clin. Invest., 28, 86. Case, F. H. (1951). J. Org. Chem., 16, 1541.

Davies, G., Levin, B., and Oberholzer, V. G. (1952). J. clin. Path., 5, 312.

Hemmeler, G. (1951). Métabolisme du Fer. Masson, Paris.

Henry, R. J., and Segalove, M. (1952). J. clin. Path., 5, 305.

Kaldor, I. (1955). Med. J. Aust., $2,886$.

Laurell, C. B. (1952). Pharmacol. Rev., 4, 371.

Partington, J. R. (1937). A Text-book of Inorganic Chemistry, 5th ed., p. 531. Macmillan, London.

Peterson, R. E. (1953). Analyt. Chem., 25, 1337.

Ramsay, W. N. M. (1958). Advanc. clin. Chem. $1,1$.

Rath, C. E., and Finch, C. A. (1949). J. clin. Invest., 28, 79.

Trinder, P. (1956). J. clin. Path., 9, 170.

Ventura, S. (1952). Ibid, 5, 271.

Webster, D. (1960). Ibid, 13, 246. 